\title{
OMNIBUS LAW - JOB CREATION LAW IN HUMAN RIGHTS PERSPECTIVE
}

\author{
Suhariwanto \\ Law Faculty, University of Surabaya \\ hari_lawfirm22@yahoo.com
}

\begin{abstract}
The Omnibus Law, The Job Creation Law, which was passed on October 5, 2020, is a law that contains 11 (eleven) clusters. One of the 14 (fourteen) clusters is the Employment cluster, which is included in Chapter IV. The purpose of enacting this Job Creation Law was to improve the investment or business climate, starting from MSMEs, Regional-owned Enterprises, State-owned Enterprises, and large-scale industries so that they can grow and develop together to accommodate more jobs, improve the quality of the workforce, and protect the labour force. The objectives can be seen from the juridical preamble of article 27 paragraph (2) of the 1945 Constitution and article 33 of the 1945 Constitution as well as the factual considerations of letters (a) to (f) "sociolegal spirit" which is the basis for the enactment of the Omnibus Law of Job Creation is also in line with the principles that are upheld in human rights, especially regarding "Social and Economic Right", as the basic needs of workers or labourers.
\end{abstract}

\section{Keyword: Omnibus Law of Job Creation and Human Rights.}

\begin{abstract}
Abstrak: Omnibus Law Undang Undang Cipta Kerja, yang telah di sahkan pada tanggal 5 Oktober 2020, merupakan undang-undang yang materi muatannya berisi 11 ( sebelas ) klater. Dari 14 ( empat belas ) klater tersebut, salas satunya adalah klater Ketenagakerjaan, yang dimuat dalam Bab IV. Tujuan membentukan UU Cipta kerja ini untuk meningkatakan iklim investasi atau usaha, mulai dari UMKM, BUMD, BUMN dan Industri berskala besar supaya dapat bertumbuh, berkembang secara bersama-sama, sehingga dapat menampung lebih banyak lapangan kerja, disertai peningkatan kualitas tenaga kerja dan perlindungan tenaga kerja. Tujuan ini dapat dilihat dari konsideran Yuridis pasal 27 ayat ( 2 ) UUD 1945 dan pasal 33 UUD 1945 maupun konsideran factual huruf ( a )sampai dengan ( f ) "sosiolegal spirit "yang menjadi landasan pijak pembentukan Omnibus Law Cipta Kerja tersebut juga sejalan dengan prinsip-prinsip yang dijunjung tinggi dalam Hak - Hak Asasi Manusia, utamanya tentang “ Social and Economic Right “, sebagi kebutuhan dasar para pekerja atau buruh.
\end{abstract}

Keywords : Omnibus Law Cipta Kerja dan Hak Asasi Manusia .

\section{INTRODUCTION}

The State Government System of the Republic of Indonesia, which is regulated by the 1945 Constitution, clearly states that "Indonesia is a country which is based on law (rechtsstaats), not based on mere power (machtsstaats). In terms of industrial relation, the constitutional basis used by the government and citizens is the provision contained in article 28D paragraph (2) of the 1945 Constitution which states "Everyone has the right to work and to receive fair compensation and treatment in a working relationship." In the juridical consideration, the formation of the omnibus law of Job Creation includes the provisions of Article 27 (2) of the 1945 Constitution and Article 33 of the 1945 Constitution. The provisions of Article 27 (2) of the 1945 Constitution clearly state that "Every citizen has the right to work and livelihood. which is worthy of humanity". Meanwhile, the provisions of Article 33 of the 1945 Constitution explicitly stipulate that:

(1) The economy is to be structured as a common endeavor based on familial principles.

(2) Production sectors that are vital to the state and that affect the livelihood of a considerable part of the population are to be controlled by the state.

(3) The land and the waters as well as the natural riches therein are to be controlled by the state to be exploited to the greatest benefit of the people.

Thus, the content of the Omnibus Law of Job Creation must be in line with the two articles of the 1945 Constitution. The Job Creation Law, which contains 11 (eleven) clusters, is intended to provide convenience for every citizen who wishes to do business and develop a business, by balancing micro, small and medium enterprises (MSMEs), cooperatives, Regional-owned Enterprises, Stateowned Enterprises, and large-scale industries, to grow together. Of the 11 (eleven) clusters, the employment cluster raises prolonged pros and cons. The focus of this paper is the laborers' category 
regulated in the Job Creation Law, which is contained in CHAPTER IV Concerning Manpower. Manpower usually includes at least two parties, namely the owner/company and the workers/labourers. In industrial relations theory, as referred to in the provisions of article 1 number 16 of Law 13/2003 concerning Manpower, it is clearly stated that "Industrial relations shall be a relations system established between actors in the production of goods and/or services, which consists of representatives of entrepreneurs, workers/labors, and the government based on values of Pancasila and the Constitution of 1945."

Industrial relation has also been defined by several scholars, namely:

a. P. Siagaan: "In general, industrial relation is defined as the formal relations that exist between management groups and working groups within an organization" (Manajemen Sumberdaya Manusia 2002: 327-328).

b. Sri Haryani: "Industrial relation is a relationship that discusses all aspects and problems of the economics, social, politics, and culture which are either directly or indirectly related to the relationship between workers/labourers and employers" (Hubungan Industrial di Indonesia 2002: 3).

In an industrial relation, the government role is called tripartite(Manajemen Sumberdaya Manusia, 2002: 328). Sentanoe Kertonegoro: "The term industrial relation gives a narrow impression as if it only concerns the relationship between employers and workers. Whereas industrial relation covers a very broad aspect, namely socio-cultural, psychological, economic, political, legal, and national defense aspects so that industrial relation does not only include employers and workers but also involves the government and the society in a broad sense (Hubungan Industrial, 1999: 4.)

Based on the notions regulated by Law/13-2003, as well as the opinions of the scholars mentioned above, the essential elements of industrial relation can be described as follows:

a. there is an industrial relation system.

b. there are actors including entrepreneurs, workers/labourers, and the government.

c. there are production processes of goods and/or services.

Industrial relation was intended to replace the term labor law. The replacement of the term was based on the consideration that the term industrial relations concerns, not only the relationship between workers/labourers and independent employers but also other factors such as economic, political, and cultural so that the term labor relation was not considered accurate to describe the real labor problem anymore. Thus, in industrial relations, the relationship between workers/labourers and employers does not only have limitations but also requires intervention from the government.

In the theory of employment relations, Law/13-2003 recognizes two terms, namely: Industrial Relations and Employment Relations. Industrial Relation is used to describe the relationship between employers/companies and workers/labourers and the government. Meanwhile, EmploymentRelations is used to describe the relationship between employers and workers/labourers in a work agreement that contains elements of work, orders, and wages. This is under the provisions of article 1 number 15 Law No 13/2003 which stipulates that "An employment relation is a relationship between an entrepreneur and a worker/labourer based on a work agreement, which contains the elements of a job, wages and work order."

Meanwhile, the provisions of article 1 number 14 Law No 13 / 2003 clearly state that "Work agreement is an agreement made between a worker/labourer and an entrepreneur or an employer that specifies work requirements, rights, and obligations of the parties." Article 1601a of the Civil Code provides the formulation of "A labour agreement is an agreement in which one party, the labourer, agrees to render his services to the other party, the employer, for a specific term in return for remuneration."

Concerning the work agreement regulated by Article 1601a of the Civil Code, Soepomo argued that it is incomplete because the workers/labourers are the only ones who bind themselves, while the employers do not. The two parties should bind themselves together, and such formulation is influenced by the mindset that places the employer in a stronger economic position than the worker/labourer(Hukum Perburuhan, Bidang Hubungan Kerja, 1980: 4).

At the beginning of its development, labour laws were included in the civil law/private law category, which was based on the principle of freedom of contract (Pacta sunt servanda). Based on this principle, every person is given the freedom to determine the contents of his agreement as well as the 
terms according to the provisions of article 1338 of the Civil Code which clearly states that "all valid agreements apply to the individuals who have concluded them as law."

The logical consequence of the freedom of contract principle application in industrial relation is to position the worker/labourer as the party unable to refuse the conditions given by the employer because the worker is the party who needs the agreement the most to be accepted to work to fulfill and support their basic needs. Apart from that, from the socio-economic aspect, the employer/company has a higher position than the worker/labourer.

Based on this reality, the presence of the government is highly required to balance the interests of employers/companies with the interests of workers/labourers with the working relations in a company. In the welfare state concept, which places the state responsible for creating welfare for the community, the state through the role of the government can intervene in several aspects, such as:

a. the aspects of the formation of laws and regulations;

b. the aspects of the implementation of laws and regulations and;

c. the law enforcement aspects.

Government intervention concerning the three aspects mentioned above, in the context of industrial relation as outlined in the work agreement with the principle of freedom of contract, is something that must be done considering several reasons as follows:

1. Sociologically, the Parties, namely workers/labourers and employers, are in a position that is not equal since employers have a stronger "bargaining power" compared to workers/labourers. Thus, it takes the presence of the government to balance the bargaining position of the two parties;

2. The free-market era requires the presence of the government to balance various interested parties, including workers/labourers and employers to ensure that the free market can run without sacrificing the smaller community who do not have the ability to compete. In a freemarket economic system, the formation of regulations, implementation of rules, and enforcement of legal regulations that eliminate fundamental rights of workers/labourers can hinder the free market itself;

3. Affirmative action and the concept of the welfare state can be used as a basis for correcting the presence of the State through the government to manage the regulations in laws and regulations in the field of labour law to create social justice.

\section{RESEARCH METHOD}

This research applies research methods using the statute approach and conceptual approach.

\section{RESEARCH PROBLEM}

Based on the problems that have been described above, the formulation of the problem can be put forward as follows: Is the Omnibus law of Job Creation, the Employment cluster, in harmony with the provisions of Articles 27 (2) and 33 of the 1945 Constitution?

\section{RESULT AND DISCUSSION}

\section{Indonesian government is responsible for the welfare of the people.}

The beginning of the twentieth century was marked by the change in the paradigm of democratic thought that placed the State as a Police State into a welfare State. This paradigm shift of thinking is based on the empirical experience of countries when implementing a police state that has failed to participate in creating social welfare. In the concept of a welfare state, the State is given the space to interfere with all the affairs of its citizens. The paradigm of thinking that places the State responsible for the welfare of the people is in line with the principles adhered to by Indonesia, as a Pancasila democracy which in the preamble to the 1945 Constitution, includes 4 main ideas, namely:

1. The state protects the entire Indonesian nation based on unity by realizing social justice for all Indonesian people.

2. The state wants to realize social justice for all people.

3. The state is based on people's sovereignty, democracy, and representative deliberation.

The State system that is formed in the Constitution must be based on the sovereignty of the people and based on representative deliberation. This principle is following the nature of Indonesian 
society. The state is based on the One and Only God according to the basis of just and civilized humanity

Therefore, the Constitution must contain the obligation of the government and other state administrators to maintain the noble human character and uphold the noble moral ideals of the people. Omnibus Law of Job Creation, indeed came from the government's initiative proposals, which was originated from the government's desire to crystallize these ideas, especially those related to realizing justice for all Indonesian people. This suggestion by the government had been reflected in the speech of President Ir. Djoko Widodo in the President's inauguration on October 20, 2019, which was then ratified before the DPR session, on October 5, 2020. It means that in approximately 1 (one) year, the government and the DPR were working hard to finalize the Omnibuslaw of Job Creation, as an umbrella law to stimulate the investment climate, improve the quality of human resources and protect the workforce. When it was legalized, there was resistance from part of the community, especially among workers/labourers because there was an assumption that Omnibus Law of Job Creation Law, does not side with the workers/labourers.

\section{Content of Employment Cluster of Omnibus law of Job Creation.}

The arrangement of the employment cluster of the Job Creation Law, which is an integral part of the other 10 (ten) clusters, is intended to strengthen the protection of the workforce and increase the role of labour in supporting the investment ecosystem. Based on these considerations, the government intends to change, eliminate, or set new arrangements of the provisions set out in:

a. Law Number 13 of 2003 concerning Manpower (State Gazette of the Republic of Indonesia of 2003 Number 39, Supplement to the State Gazette of the Republic of Indonesia 4279);

b. Law Number 40 of 2004 concerning the National Social Security System (State Gazette of the Republic of Indonesia of 2004 Number 150, Supplement to the State Gazette of the Republic of Indonesia 4456); and

c. Law Number 24 of 2011 concerning Social Security Administering Bodies (State Gazette of the Republic of Indonesia of 2011 Number 116, Supplement to the State Gazette of the Republic of Indonesia 5256).

The second part of article 89 of the Employment cluster states that "Several provisions in Law Number 13 of 2003 concerning Manpower have been changed, and the changes have created various perceptions, such as:

\section{A. PKWT of Article 56 is amended as follows:}

1. Work agreement is made for a certain time or for an unspecified time.

2. The work agreement for a specified period as referred to in paragraph (1), is based on: (a) The period; or (b), the completion of certain work

3. The period or completion of certain work as referred to in paragraph (2) shall be determined based on the agreement of the parties.

4. Further provisions regarding a work agreement for a specified period and the completion of a certain job shall be further regulated by a Government Regulation.

The addition of the two paragraphs in article 56 is meant to provide space for the Government to make policies in determining the criteria regarding what types of work qualify as the types of work that can be used as PKWT objects. And the addition of two paragraphs to article 56 does not contradict the legal spirit of the content of article 27 paragraph (2) and Article 33 of the 1945 Constitution, which is the juridical basis for the formation of the Omnibus law of Job Creation.

\section{B. Abolition of Article 59 Regulating Certain Types and Occupations.}

The abolition of Article 59 which regulated certain types and occupations has something to do with Article 56 paragraph 4. Determination of certain types of work that become the object of PKWT is regulated by a Government Regulation so that it is more flexible and can guarantee legal certainty and legal protection for workers/labourers. The removal of the provisions of article 59 can also encourage workers to be more active in improving their competence, which eventually can increase the income and welfare for workers/labourers and their families.

\section{Providing PKWT Compensation}

Between the provisions of article 61 and article 62, the provisions of Article 61A are inserted which explicitly state the following: 
1. If the work agreement for a specified period ends as referred to in Article 61 paragraph (1) letter $\mathrm{b}$ and letter $\mathrm{c}$, the employer is obliged to provide compensation money to the worker labourer.

2. Compensation money as referred to in paragraph (1) shall be given to workers/labourers who have worked for at least 1 year at the company.

3. Further provisions regarding the amount of compensation money shall be regulated in government regulation.

The insertion of Article 61A provisions favours the interests of workers/labourers with PKWT status. In the previous provisions, PKWT workers did not receive compensation money. Thus, it can be interpreted as "social and economic right" of workers/labourers as mandated by Article 27 paragraph (2) and Article 33 of the 1945 Constitution, which is used as the basis for the formation of the Omnibus law of Job Creation, the Employment cluster, is truly crystallized in the material content of article 61A, the Employment cluster.

\section{Abolition of articles 64 and article 65}

Article 64 and Article 65 of Law Number 13/2003, which were removed from the Employment cluster are appropriate. This is because the article regulates the relationship between the outsourcing company and the employing company. The legal relationship between the two companies is subject to the provisions stipulated in the Civil Code. Therefore, the elimination of article 64 and article 65 further emphasizes that it is the outsourcing company that is fully responsible for workers/labourers employed in the employing company. Therefore, the outsourcing company is required to be in the form of a limited liability company so that the protection of workers' rights is getting more clarity compared to the condition before the provisions of articles 64 and 65 of Law $13 / 2003$ were removed.

\section{E. Amendments to the provisions of Article 66 concerning Outsourcing Companies}

The provisions of Article 66 were amended so that they read as follows:

1. The work relation between the outsourcing company and the workers/labourers employed is based on a work agreement for a specified or unspecified time.

2. Protection of workers/labour, wages and welfare, working conditions, and disputes that arise are the responsibility of the outsourcing company.

3. The outsourcing company as referred to in paragraph (2) is in the form of a legal entity and is obliged to acquire business licenses.

4. Further provisions regarding the protection of workers/labour as referred to in paragraph (2) and business licenses as referred to in paragraph (3) shall be regulated in a Government Regulation.

The amendment to the provisions of article 66 of the Employment cluster is an affirmation that workers/labourers who work for outsourced companies, either based on PKWT or PKWTT, receive protection in terms of both wage and welfare aspects. The government is responsible for safeguarding the guarantee of the rights and welfare of workers/labourers

\section{F. Amendments to Article 77 Concerning Working Hours}

The provisions of Article 77 are changed so that they read as follows:

1. Every employer is obliged to implement the working hour provisions.

2. The working hours as referred to in paragraph (1) shall be no longer than 8 (eight) hours in 1 (one) day and 40 (forty) hours in 1 (one) week.

3. The implementation of working hours for workers/labourers in a company is regulated in a work agreement, company regulation, or collective working agreement.

The changes outlined in article 77 of the employment cluster do not change the essence of article 77 of Law number 13/2003. The change is merely a simplification of the sentence, making it easier to understand. The phrases in paragraph 3, article 77, which states that the implementation of working hours for workers/labourers in a company is regulated in a work agreement, company, or collective work agreement, does not provide space for employers to determine working hours without the consent of the workers' organization in the company. Thus, it is not true if this provision is perceived by workers/labourers that they will only get a break once a week.

\section{G. Amendments to Article 79 Concerning Break and Leave Time}

The provisions of Article 79 are changed so that they read as follows:

1. Employers are obliged to provide (a) break and (b) leave 
2. The break period as referred to in paragraph (1) letter a must be provided to workers/labourers in terms of:

a. Breakwithin working hours, at least half an hour after working for 4 (four) hours continuously and the break time does not count as working hours; and

b. Weekly break for 1 (one) day after 6 working days in 1 (one) week

3. The leave as referred to in paragraph (1) letter $b$ that must be given to workers/labourers is annual leave, at least 12 (twelve) working days after the worker/labourer has worked for 12 (twelve) months continuously.

4. The implementation of annual leave as referred to in paragraph (3) shall be regulated in a work agreement, company regulations, or collective work agreement.

5. In addition to the break and leave as referred to in paragraph (1), paragraph (2), and paragraph (3), the company can provide extended leave as stipulated in the work agreement, company regulations, or collective work agreement.

The debate regarding the provision of extended leave which is regulated by paragraph 5 , Article 79, amended by the original text of Article 79 paragraph (2) letter d, is due to a misperception because extended leave is also regulated and given as stipulated in paragraph 5 of Article 79 of the employment cluster. The amendment article does not eliminate the right to extended leave in any way.

\section{H. Between Article 88 and Article 89 are inserted $88 \mathrm{~B}$ and $88 \mathrm{C}$}

The insertion of article $88 \mathrm{~B}$ reads as follows. Wages are determined based on: a. time unit; and/or b. achievement unit. In addition, the insertion in Article $88 \mathrm{C}$ reads:

(1) The Governor determines the minimum wage as a safety net

(2) The minimum wage as referred to in paragraph (1) is the provincial minimum wage.

Meanwhile, the regency/city minimum wage stipulated in Article 89 of Law Number 13 / 2003 was removed. The rejection of the abolition of article 89 is very reasonable. This is because the economic conditions in each district/city are not the same. Therefore, the provision of the minimum wage set by the governor must also be followed by the regency/city minimum wage, so that it does not cause social inequality.

Getting a decent wage is a basic right of workers/labourers which are protected by the constitution, in this case, Article 27 paragraph (2) and Article 33 of the 1945 Constitution, which is the basis for the formation of this omnibus law of job creation. Meanwhile, Article 88D paragraph (4) stipulates that "Further provisions regarding minimum wages are further regulated by government regulations". Omnibuslaw created this work, gave a role to the government to seriously prosper the society. This is because Indonesia, as a state of law and Pancasila democracy, must truly be able to manifest the values of Pancasila in all aspects of people's lives. In the context of omnibus law, work protection for workers/labourers receives special attention because workers/labourers have limitations when compared to employers.

\section{Amendment to Article 156 concerning Termination of Employment and Severance Pay}

The provisions of Article 156 are amended so that they read as follows:

(1). In the event of termination of employment, the employer is obliged to pay severance pay and/or compensation.

(2) The minimum amount of the severance pay as meant in paragraph (1) shall be stipulated as follows:

a. Amounting to wage for one month, in the case of the working period being less than one year;

b. Amounting to wage for 2 (two) months, in the case of the working period being one year or more than 2 (two) years;

c. Amounting to wage for 3 (three) months, in the case of the working period being2 (two) years but less than 3 (three) years;

d. Amounting to wage for 4 (four) months, in the case of the working period 3(three) years but less than 4 (four) years;

e. Amounting to wage for 5 (five) months, in the case of the working period being 4(four) years but less than 5 (five) years;

f. Amounting to wage for 6 (six) months, in the case of the working period being 5(five) years but less than 6 (six) years; 
g. Amounting to wage for 7 (seven) months, in the case of the working period being6 (six) years but less than 7 (seven) years;

h. Amounting to wage for 8 (eight) months, in the case of the working period being 7(seven) years but less than 8 (eight) years;

i. Amounting to wage for 9 (nine) months, in the case of the working period being 8(eight) years or more;

(3). The calculation of the compensation as referred to in paragraph (1) shall be determined based on:

a. Amounting to wage for 2 (two) months, in the case of the working period being 3(three) years or more;

b. Amounting to wage for 3 (three) months, in the case of the working period being6 (six) years or more but less than 9 (nine) years;

c. Amounting to wage for 4 (four) months, in the case of the working period being 9(nine) years or more but less than 12 (twelve) years;

d. Amounting to wage for 5 (five) months, in the case of the working period being 12(twelve) years or more but less than 15 (fifteen) years;

e. Amounting to wage for 6 (six) months, in the case of the working period being 15(fifteen) years or more but less than 18 (eighteen) years;

f. Amounting to wage for 7 (seven) months, in the case of the working period being 18 (eighteen) years or more but less than 21 (twenty-one) years;

g. Amounting to wage for 8 (eight) months, in the case of the working period being2 1 (twenty- one) years or more but less than 24 (twenty-four) years;

(4) Employers may provide compensation money as stipulated in work agreements, company regulations, collective working agreements.

(5) Further provisions regarding the amount of severance pay and compensation in the event of termination of employment as referred to in Article 154A paragraph (I) shall be regulated by government regulation.

With the abolition of provision 166, workers/labourers or their heirs may seem to have the potential to lose their rights amounting to 15 months of wages. However, if the omnibus law of job creation, in the amendment of article 6 paragraph (2) on the fourth part regarding the Social Security Administration which determines that "BPJS Ketenagakerjaan as referred to in article 5 paragraph (2) letter $\mathrm{b}$ organizes the following programs:
a. Accident insurance;
b. Old age benefits;
c. Pension plan;
d. Life insurance; and
e. Job loss guarantee

Another benefit can be seen in the provisions stipulated in Part Five which regulates other Awards, as stipulated in Article 92 as follows:

1. To improve the welfare of workers, employers based on this Law give other awards to workers/laborers.

2. Other awards as referred to in paragraph (1) shall be given provided that:

a. Workers/labourers who have worked for less than 3 years, 1-month wages;

b. Workers/labourers who have worked for 3 (three) years or more, but less than 6 (six) years, 2 (two)-month wages;

c. Workers/labourers who have worked for 6 (six) years or more, but less than 9 (nine) years, 3 (three)-month wages;

d. Workers/labourers who have worked for 9 (nine) or more, but less than 12 (twelve) years, 4(four)-month wages;

e. Workers/labourers who have worked for 12 (twelve) years or more, 5 (five)-month wages.

Thus, the provisions of Article 92 paragraph (6) mandates the government to further regulate the awarding. Mathematically speaking, by referring to the aforementioned provisions, the workers/labourers' normative rights when they stop working can be up to 22 times their monthly wages, excluding the Job Loss Guarantee provided by BPJS. Compared to the provisions of Law number 13/2003 concerning manpower, workers/labourers who stop working normally can receive 32 
times their monthly wages. This very sharp difference is what causes workers/labourers to refuse the job creation law. Therefore, these regulatory changes need to be followed up by government regulation, so that the job loss guarantee regulated in the BPJS can close the gap.

\section{CONCLUSIONS}

\section{Conclusions:}

Based on the explanations that have been put forward starting from the problematics, problem formulation, and discussion, it can be concluded that:

1. Omnibus law of Job Creation is a law which includes 11 (eleven) clusters, including the workforce cluster, which aims to increase and expand employment and business fields, starting from MSMEs, Regional-owned Business, State-owned Business, large-scale industry, improvement of manpower quality, and labour protection;

2. Chapter IV: Employment Cluster article 89, which regulates the amendment, elimination, and insertion of articles from Law number 13 / 2003 and followed by Article 90 concerning BPJS, precisely aims to improve the quality of the workforce, protect and improve the welfare of workers in a balanced manner by creating a healthy investment climate.

3. The government needs to clarify the amendment of articles, the abolition of articles, and insertion of articles which can still lead to multiple interpretations, both pros, and cons, in government regulations to provide certainty for both workers/labourers, employers, and the

\section{Suggestions:} community to comply with these rules.

The Omnibus Law on Job Creation has both advantages and disadvantages. In the constitutional state and Pancasila democracy, which is the basis of the foundation for the administration of the government in Indonesia, it is suggested, for the public or government who assess the omnibus law of job creation that the content is not yet following the juridical considerations of Article 27 paragraph (2) and Article 33 of the 1945 Constitution, as the basis for its formation; The followings are the rights guaranteed by the constitution that:

1. Every citizen has the right to apply for a Judicial Review to the Constitutional Court;

2. The legislators have the authority to conduct a legislative review;

3. The government has the opportunity to make a government regulation to clarify the content that is still multi-interpretative.

\section{REFERENCES}

Kertonegoro, Sentanoe, Hubungan Industrial, Hubungan antara Pengusaha dan Pekerja (Bipartit) dan Pemerintah (Tripartit), YLKI, Jakarta, Tahun 1999.

Siagian. Sondang P, Manajemen Sumber Daya Manusia, Cet.20, Bumi Aksara, Jakarta, 2002.

Sriharyani, Hubungan Industrial di Indonesia, Yogyakarta, 2002.

Naskah Akademik Omnibus Law RUU Cipta Kerja .

Naskah RUU Omnibus Law Cipta Kerja - BALEG -RJ 2020065- 10022. 